\title{
It all Started with Gunner James
}

\author{
Cameron Harvey*
}

This article is about Lord Denning who needs no introduction. It is not a learned analysis of his reasons for judgment. It focuses, for fun, on three aspects of his distinctive judicial writing style.

Before I researched the article, I had a clear recollection of two or three delightful Denning judgments, such as Beswick v. Beswick. 'I imagined that there were more than I could remember or knew of. My colleagues were of some help; however, their recollection, similar to mine, turned out to be more general than specific. I realized that I was going to have to explore this legendary corner of Lord Denning's judicial career the hard way. Thus, I methodically perused all of his reported reasons for judgment.

I uncovered not only additional Denning gems, featuring his distinctive style of reciting the facts, but also I discovered what I call the unique Denning opener and his remarkable cast of "old" litigants. First, I shall deal with his distinctive style of recounting the facts, then turn to his openers, and finally introduce you to his "old" litigants.

It is obvious that Lord Denning very much enjoyed doing the facts. In most of the published cases of the Court of Appeal in which he was involved, he described the facts for the court in his reasons for judgment. Recently, in his book The Family $S t o r y^{2}$ he confessed to something that had become obvious from his reasons for judgment. He is an inveterate story-teller. It was his distinctive style to recount the facts in the form of a story. On occasion in his reasons for judgment Lord Denning specifically referred to the facts as the story and to his recitation of the facts as a telling of the story.

Ionian Bank Ltd. v. Couvreur ${ }^{3}$

"... the story is a little complicated and I must recite the facts."

Reid v. Commissioner of Police of the Metropolis ${ }^{4}$

"The centre-piece of this story is a pair of candelabra..."

*Of the Faculty of Law, University of Manitoba, Winnipeg, Canada. This article was first published in XVII Gazette (1983) of The Law Society of Upper Canada.

1. [1966] Ch. 538.

2. Butterworths, London, 1981.

3. [1969] 2 All E.R.651, 652.

4. [1973] Q.B.551, 557 . 
Cory Lighterage Ltd. v. T.G.W.U.

"In this action the leading actor is Andrew Shute, but he is the only one on the stage who has not given evidence. To some he is the hero. To others the villain of the piece."

Byanston Finance Ltd. v. de Vries ${ }^{6}$

"This case reads like a play. It has many acts and scenes. On the stage now the principal characters are ... In previous scenes there appeared ..."

Midland Bank Trust Co. Ltd. v. Green ${ }^{7}$

"The Greens are a Lincolnshire farming family. This story might be called The Green Saga."

One of Lord Denning's most remarkable pieces of storytelling is, of course, his Report on the security aspects of the Profumo affair. ${ }^{9}$ This is no ordinary royal commission report. Lord Denning himself uses it as one of his examples of his style of writing in The Family Stoy. Lord Denning's storytelling approach to the subject made the Report perhaps the most readable, engaging H.M.S.O. publication ever.

In The Family Stony Lord Denning describes his approach to judgment writing:

"I try to make my judgment live .. I start my judgment, as it were, with a prologue - as the chorus does in one of Shakespeare's plays - to introduce the story. Then I go from act to act as Shakespeare does - each with its scenes drawn from real life ... I draw the characters as they truly are - using their real names ... I avoid long sentences like the plague: ${ }^{10}$ because they lead to obscurity. It is no good if the hearer cannot follow them ... I refer sometimes to previous authorities - I have to do so - because I know that people are prone not to accept my views unless they have support in the books. But never at much length. Only a sentence or two. I avoid all reference to pleadings and orders - They are mere lawyer's stuff. They are unintelligible to everyone else. I finish with a conclusion - an epilogue - again as the chorus does in Shakespeare. In it I gather the threads together and give the result." ${ }^{11}$

Thus, the Denning style of reciting the facts is a crisp, captivating story, featuring short, stacatto sentences and occasionally a touch of whimsy. His accounts of the facts may be quite brief (and this is probably the image of them that most people carry in their mind), for example $R$. v. Hillingdon Borough Council ${ }^{12}$ or they may be

5. [1973] 2 All E.R.558, 561

6. $[1975] 2$ All E.R.609, 612.

7. [1979] 3 All E.R.28, 30. See also [1982] 2 W.L.R.1, 4.

8. See similarly Wallersteiner v. Moir [1974] I W.L.R.991, 955; Re Brocklehurt [1978] 1 All E.R.767, 769; and New Zealand Government Property Corporation v. H.M. ES S. Ltd. [1982] 2 W.L.R.837, 839.

9. Cmnd. 2152 of 1963.

10. In The Family Stony, supra note 2, at p. 203 Lord Denning expresses his admiration for a predecessor, George Jessel, M.R.: "He used short, staccato sentences."

11. Supra note 2, at pp. 207-208.

12. [1980] 3 All E.R.413. 
several paragraphs, even pages long, for example Broome v. Cassell Ltd. ${ }^{13}$ In any event, brief or lengthy, the result is a very effective, delightful short story.

The instantly recognizable Denning factual account was not present in his earliest reported reasons for judgment, such as Fletcher v. Fletcher, ${ }^{14}$ Norton v. Norton, ${ }^{15}$ Minister of Pensions v. Chennell, ${ }^{16}$ and Miller $\mathrm{v}$. Minister of Pensions. ${ }^{17}$ His recitation of the facts in these and other early cases is unremarkable. And then the unmistakable style was there. It all started with Gunner James:

"Gunner James joined the army on July 24, 1941, at the age of thirty-two. In January 1943, he had a swelling on the right side of his neck which gradually spread. He was sent to hospital, when a diagnosis of Hodgkin's disease was made. In April, 1943, he was discharged on account of it. He claimed a pension. It was rejected by the Minister. In February, 1946, he died on account of the disease. His widow claimed a pension. Her claim was also rejected by the Minister. She appealed to a tribunal who, on September 18, 1946, rejected her appeal. She did not apply to the tribunal for leave to appeal within the six weeks allowed by the rules of the tribunal. On November 21, 1946, the case of Donovan v. Minister of Pensions, which was also a case of Hodgkin's disease, was decided in favour of the widow. When knowledge of this decision came to Mrs James's advisers, they sought from the tribunal leave to appeal out of time. The tribunal itself and the President of the Pensions Appeal Tribunals refused the application, refusing to extend the time or to grant leave. The widow now applies for leave to appeal." 18

I do not suppose that many of you, even devotees of Denning judgments, recall the forgoing case. It is not entirely in the classic Denning style. For instance, the second sentence should end at "neck" and the next sentence should be, "It gradually spread". Similarly, the third sentence should end at "hospital" with the remainder made into a new sentence. However, Fames v. Minister of Pensions is the seminal judgment.

The refinement, over the years, in the Denning style can be seen in Deeble v. Robinson, ${ }^{19}$ Stupple v. Royal Insurance Co. Ltd. ${ }^{20}$ and R. v. Hillingdon Borough Council: ${ }^{21}$

Deeble v. Robinson

"Mr Deeble has a milk round. He sells milk to people at the doors of their houses. $\mathrm{He}$ runs his business from a dairy building where he keeps his

13. [1971] 2 Q.B.354.

14. [1945] 1 All E.R.582; this is Lord Denning's first reported judgment.

15. [1945] P.56.

16. [1946] 2 All E.R.719.

17. [1947] 2 All E.R.372.

18. Fames v. Minister of Pensions [1947] K.B.867.

19. [1954] 1 Q.B.77, 81 .

20. [1971] 1 Q.B. 50, 67.

21. Supra note 12 , at p. 417. 
equipment, refrigerator, spare milk bottles, and so forth, and a stable where he keeps his horse and float. His round is seven streets adjoining the premises. He does not actually have a shop as ordinarily understood. His lease of these premises is coming to an end, and he wants to stay on there. This depends on whether the premises come within the definition of a "shop" in the Leasehold Property (Temporary Provisions) Act, 1951."

Stupple v. Royal Insurance Co. Ltd.

"On Friday, September 27, 1963, near Longfield, in Kent, a gang of robbers laid in wait for a bullion van. It was about mid-day. They had come down from London in convoy. They were in a Land Rover, a Dormobile and a lorry. All three vehicles had recently been stolen. Whilst waiting for the bullion van, they went on to a village green and kicked a ball about. It was a red plastic ball. The local folk saw them. Soon afterwards the gang left. They got themselves ready. They had iron bars in their hands. One had an Indian club. They ambushed the bullion van. They must have known its movements. It belonged to Martins Bank and had been round the branches collecting money. One was the branch at Welling. The robbers stopped the van and overcame the driver and guard. They stole $£ 87,30010$ s, and went off."

$R$. v. Hillingdon Borough Council

"She was born in Ethiopia. Her name was Sophia Abrahim. In 1975 she was 19 years of age. She had a baby son David aged 2. An Englishman then came to Addis Ababa. He was Alan Streeting. He was aged 25. He asked Sophia to marry him. He told her he was divorced. They were united in marriage in Addis Ababa on 17th May 1975. She kept her marriage certificate. He brought her and the baby over to England where they stayed for some weeks. He was employed by an American company and worked in Libya. He took a flat in Athens in Greece. Sophia and her child lived there and he went to and fro to them. He also brought them again to England for a holiday. Then tragedy struck. In Libya he had a heart attack and died. It was on 27th April 1979. His company flew his body back to England for burial. They arranged for Sophia and her little boy to come here for the funeral. It was at Brighouse in Yorkshire. It then transpired that he had not been divorced at all. His wife was still alive in England. So his marriage to Sophia was a bigamous marriage. It was a nullity. But his company took pity on her. They arranged for her to go back to Greece to sort out her affairs there. They paid her fare. But when she arrived at Athens airport, she was not allowed to enter, on the ground that she had not a valid residency permit. So she returned to England. That was on 25th May 1979. His company then put her and the baby up at an hotel here. But they could not keep her indefinitely. So they went with her to the housing department at Hillingdon. That was on 4th June 1979. They presented her and her child as homeless. The housing department made all sorts of inquiries, from Greece and from Ethiopia, to see if she could be found a home there. But these were all fruitless. The Hillingdon housing department 
arranged for temporary accommodation for her at a guest house, for bed and breakfast, at $£ 7.75$ a night. She also got supplementary benefit (national assistance) from which she could pay for her other meals and clothes etc. But eventually the Hillington council decided that they could pay no longer for her accommodation."

Everyone has his favourite Denning judgments. In The Family Story Lord Denning chose the following cases to illustrate the style: Beswick v. Besmick, ${ }^{22} \mathrm{Hinz}$ v. Bern, ${ }^{23}$ Lloyds Bank Ltd. v. Bundy, ${ }^{24}$ Ex p. Hook, ${ }^{25}$ and Mcllkenny v. Chief Constable of the West Midlands. ${ }^{26}$ To those cases I add Videan v. British Transport Commission, ${ }^{27}$ Broome v. Cassell Ltd., ${ }^{28}$ Gray v. Barr, ${ }^{29}$ Reid v. Commissioner of Police of the Metropolis, ${ }^{30}$ and Re Brocklehurst. ${ }^{31}$ In these judgments Lord Denning demonstrates his ability to deal in humour, pathos, tragedy, intrigue, and adventure. Space does not permit the inclusion of excerpts from all of these cases. I have chosen four which are representative.

Exp. Hook

"To some this may appear to be a small matter, but to Mr Harry Hook, it is very important. He is a street trader in the Barnsley market. He has been trading there for some six years without any complaint being made against him; but, nevertheless, he has now been banned from trading in the market for life. All because of a trifling incident. On Wednesday, October 16, 1974, the market closed at 5.30. So were all the lavatories, or 'toilets' as they are now called. They were locked up. Three-quarters of an hour later, at 6.20, Harry Hook had an urgent call of nature. He wanted to relieve himself. He went into a side street near the market and there made water, or 'urinated', as it is now said. No one was about except one or two employees of the council, who were cleaning up. They rebuked him. He said: 'I can do it here if I like.' They reported him to a security officer who came up. The security officer reprimanded Harry Hook. We are not told the words used by the security officer. I expect they were in language which street traders understand. Harry Hook made an appropriate reply. Again we are not told the actual words, but it is not difficult to guess. I expect it was an emphatic version of 'You be off.'

22. Supra note 1, at p. 549 .

23. [1970] 2 Q.B.40, 42.

24. [1975] Q.B.326, 334.

25. [1976] 1 W.L.R.1052, 1055.

26. [1980] 2 W.L.R.689, 696 et seq.

27. [1963] 2 Q.B.650, 660.

28. Supra note 13 , at p. 371.

29. [1971] 2 All E.R.949.

30. [1973] Q.B.551.

31. Supra, note 8. For the Denning addict I suggest for additional reading the following cases which deserve "honourable mention" at least: Wilson v. Rickett Cockrell Lid. [1954] 1 Q.B.598; Roe v. Minister of Health [1954] 2 Q.B.66; Lane v. Halloway [1967] 2 All E.R.129; Pett v. Greyhound Racing Association Lid. [1969] 1 Q.B.125; Balogh v. Cromn Coun at St Albans [1974] 3 All E.R.283; and R. v. Local Commissioner for Administration for the N. and E. Area of England [1979] 2 All E.R.881. 
At any rate, the security officer described them as words of abuse. Touchstone would say the security officer gave the 'reproof valiant' and Harry Hook gave the 'countercheck quarrelsome'; As you Like It, Act V, Scene IV.

On the Thursday morning the security officer reported the incident. The market manager thought it was a serious matter. So he saw Mr Hook the next day, Friday, October 18. Mr Hook admitted it and said he was sorry for what had happened. The market manager was not satisfied to leave it there. He reported the incident to the chairman of the amenity services committee of the council. He says that the chairman agreed 'that staff should be protected from such abuse.' That very day the market manager wrote a letter to $\mathrm{Mr}$ Hook, banning him from trading in the market."

\section{Lloyds Bank Ltd. v. Bundy}

"Broadchalke is one of the most pleasing villages in England. Old Herbert Bundy, the defendant, was a farmer there. His home was at Yew Tree Farm. It went back for 300 years. His family had been there for generations. It was his only asset. But he did a very foolish thing. He mortgaged it to the bank. Up to the very hilt. Not to borrow money for himself, but for the sake of his son. Now the bank have come down on him. They have foreclosed. They want to get him out of Yew Tree Farm and to sell it. They have brought this action against him for possession. Going out means ruin for him. He was granted legal aid. His lawyers put in a defence. They said that, when he executed the charge to the bank he did not know what he was doing: or at any rate that the circumstances were such that he ought not to be bound by it. At the trial his plight was plain. The judge was sorry for him. He said he was a 'poor old gentleman.' He was so obviously incapacitated that the judge admitted his proof in evidence. He had a heart attack in the witness-box. Yet the judge felt he could do nothing for him."

Videan v. British Transport Commission

"There is a small country station at North Tawton on the main line between Okehampton and Exeter. The stationmaster was Mr Videan, who lived in the station house with his wife and four small boys, aged six, five, three and two. They had been living there for three years, the youngest being born there. The station house was on the up side of the line, and their garden and chicken run on the other side. There was a footbridge for passengers and a barrow crossing for porters with barrows. Mrs Videan used sometimes to take the pram with a child across the barrow crossing, and one of the staff occasionally took a child across by the hand. But the children by themselves usually went by the footbridge. Mrs Videan said: 'The children were always trained to do that. They were not allowed to run about on the tracks ... But they did run out on to the platform. That was quite another matter.'

On Sunday morning, July 26, 1959, the stationmaster was having the day off, and Porter Canniford was in charge. The stationmaster was going to take his family to Exeter for the day. His wife was busy in the house getting 
everything ready for their outing. The stationmaster was outside playing with the children until the time came to go. Suddenly they found that Richard, the youngest, aged two years and two months, was missing. The stationmaster looked into the door. His wife said to him: 'Where's Richard?' He said: 'Isn't he with you?' She said: 'Bring him in when you find him. I want to get him "ready".' The stationmaster went out, through the booking hall into the booking office, and asked Porter Canniford, 'Have you seen Richard?' The porter said 'No.' The stationmaster went out on the platform followed by the porter. They saw the little boy in the 'four-foot' of the up line, a little way from the barrow crossing, and at the same moment, on that very line, a trolley coming towards him. It was the sort of trolley railway men use nowadays for getting about the line, driven by a petrol motor and capable of considerable speeds. It was then by the home signal, about 120 yards away, coming fast along the line towards the place where the little boy stood.

The stationmaster and the porter held their hands up, signalling the trolley-driver to stop. But he still came on. They ran forward. The stationmaster was in front, running as fast as he could; the porter a little behind. The trolley-driver started to slow down, but not very much. He seemed not to appreciate the danger. Still he came on. He cannot have seen the child. Only at the last moment did he see him. Only then did he apply his brake. The porter said: 'As he got very close, I could see he was really hanging on to the hand-brake, pulling as hard as he could.' But it was too late. Then the stationmaster, in a desperate effort to save his son, leaped from the platform on to the line, in the very path of the trolley. He saved his son - it seems that he pushed him down below the trolley - but he was himself killed in the instant. The little boy was badly injured. He was five and a half months in hospital, but has recovered a good deal."

Broome v. Cassell Ltd.

"The Jury gave $f 40,000$ damages. It is a large sum. How did they get to it? What facts were known to them? These I will tell.

\section{Introduction}

Early in July 1942 a large convoy of 35 merchant ships - it had the code number PQ17 - was sailing in the Arctic seas laden with materials of war for Russia. They were between North Cape and Spitzbergen near the icefields. At that time of the year there was no nightfall. It was light all the time. The convoy was approaching the dangerous part of the voyage. The German battle fleet had come up swiftly and secretly. It was lying in wait in Alten fiord, just by North Cape. It consisted of the most powerful warship afloat - the Tirpitz with the cruisers Hipper and Scheer, and six destroyers. Nearby, at Banak, was an airbase whence the German aircraft could make sorties of 400 miles to bomb the convoy. Under the sea there were German submarines watching through their periscopes for a chance to strike.

The convoy would seem an easy target. It could only make eight knots. It 
had to steam at the pace of the slowest. But it was in good hands; it was guarded by the Royal Navy. The close escort was under the command of Commander Broome, R.N., in the destroyer Keppel. It consisted of six destroyers, which were very fast, and several converted merchantmen as naval escorts, which were much slower. In support was a cruiser covering force under Rear-Admiral Hamilton in the London. It consisted of four cruisers and three destroyers. Further behind, ready to do battle, was the Home Fleet under Admiral Tovey in the Duke of York.

July 4, 1942, saw the climax. Enemy air attack was imminent. Rear-Admiral Hamilton thought it best to play for safety. He 'instructed' Commander Broome to route the convoy to the northward so that it should be 400 miles from the enemy aerodrome. But Commander Broome was bolder. He did as Nelson did. After all, 'instructions' were not orders. They were more in the nature of recommendations, as every naval officer knows. He kept an easterly course, even though it did bring him nearer the enemy. Commander Broome was right. He was the man on the spot. He had an independent command and was entitled to exercise his own judgment. He had to take advantage of low cloud when it gave cover. And he had been advised by the Admiralty that the convoy should be kept 'moving to the eastward even though it was suffering damage.' So Broome did not route it so much northward as Hamilton suggested. He kept it moving eastward as well. His decision was afterwards approved by Admiral Tovey.

Later that day the expected attack came. Suddenly at 8:22 p.m. 25 enemy aircraft appeared flying fast and low at the convoy. They were torpedo bombers and pressed home their attack with great determination. They sank two of the merchantmen. But the convoy and escort gave a good account of themselves. They shot down four of the attackers and went on in perfect formation. They were brave men. Commander Broome said to those nearby: 'Provided the ammunition lasts, Convoy PQ17 can get anywhere.'

Soon after beating off this atack, there came a warning of fresh danger. This time it was the onset of enemy surface ships. The Admiralty sent out three signals which arrived one after the other on the bridge of the Keppel, and of the other ships. The signals were, of course, in cipher:

' 9.11 p.m. Secret. Immediate. Cruiser force withdraw to westwards at high speed.

9.23 p.m. Secret. Immediate. Owing to threat from surface ships convoy is to disperse and proceed to Russian ports.

9.36 p.m. Secret. Most Immediate. My 9.23 p.m. Convoy is to scatter." The last message arrived so close on the heels of the one before that, when they had been deciphered, the signalman handed them both together to the commander. They spelt only one thing. The German battle fleet was about to attack. Everyone expected to see masts appearing on the horizon. The order to 'disperse' meant that the convoy was to split up into smaller formations, 
which were still under escort able to defend them. The next order to 'scatter' was more urgent still. It had never been given before, except once by the captain of the Jervis Bay, and he gave it only when the enemy cruisers were opening fire. It meant that the ships of the convoy were to scatter fanwise, each by himself, in every direction without escort. Leaving the escorting force to engage the enemy.

Commander Broome did as he was told. He took the Keppel into the middle of the convoy and told the commodore that the convoy was to scatter. He knew that his destroyers could not tackle the enemy fleet by themselves. So he proposed to Rear-Admiral Hamilton that they should join up with the cruiser force. Rear-Admiral Hamilton at once agreed. So Commander Broome with his escorting destroyers joined the cruisers and came under the direct command of Rear-Admiral Hamilton. The naval escorts (the converted merchantmen) were slow and could do little to protect the scattering convoy. So Commander Broome ordered them to proceed independently to Archangel. He, with his destroyers, prepared to meet the enemy.

But the threatened attack never came. The enemy fleet never appeared over the horizon. The order from the Admiralty was a mistake. The First Sea Lord, Admiral of the Fleet Sir Dudley Pound, had convinced himself that the Tirpitz must have put to sea, whereas the intelligence reports indicated that she had not. But the order was given. The convoy scattered to the four winds. Without protection, they were attacked by the enemy from the air and from beneath the sea. Many were sunk. Out of 35, only 11 reached Russian ports: 153 merchant sailors were lost and vast quantities of war material went to the bottom. It was a tragedy. A severe blow to the allied cause.

The officers made their reports. Commander Broome was not blamed by those superior to him. Nor by his brother officers. Admiral Tovey reported:

'I do not consider that the commanding officer of the Keppel was in any way to blame for the subsequent heavy losses. From the signals which he had received, he deduced, quite reasonably, that surface action was imminent: and was correct in his decision to concentrate his destroyers and join the rear-admiral commanding first cruiser squadron.'

Proof positive of the confidence in Commander Broome was that he was kept in sea-going commands and finished the war in command of the battleship Ramillies. Many persons afterwards wrote about the disaster. The official historian of the war wrote about it. He did not condemn Commander Broome. Nor did $\mathrm{Mr}$ Winston Churchill. The condemnation was made 20 years later by an author who knew nothing about the war, because he was a small boy at the time. David Irving was determined to write 'an authentic account.' His regular publishers - William Kimber \& Co. Ltd. - refused to publish it. They thought it was too dangerous. So he got Cassell \& Co. Ltd. to publish it." 
Being a good storyteller, Lord Denning endeavours to attract and capture immediately the attention of the reader. To do this he employs an impressive array of what I call openers. These are the opening sentence(s) of his judgments. I have selected a number of them and organized them into these categories: The Intriguing Opener; The Historical Opener; The Fatal and Deadly Opener; The "This is the case" Opener; The Editorial Opener; The Non-Sequitur Opener; The "This is an interesting case" Opener; The Whimsical Opener; and The Picturesque Opener.

\section{The Intriguing Opener}

Hinz v. Berry ${ }^{32}$

"It happened on April 19, 1964. It was bluebell time in Kent." Heymood v. Wellers ${ }^{33}$

"It all started in a public house."

Levinson v. Patent Steam Carpet Cleaning Co. Ltd. ${ }^{34}$

"It was a fine Chinese carpet worth $\oint^{900}$, but it needed cleaning."

Kavanagh v. Chief Constable of Devon and Cornwall ${ }^{35}$

"Mr Kavanagh wants to have a gun, perhaps many guns."

Ronds v. McNeil ${ }^{36}$

"A Yorkshire farmer had a dangerous bull."

Re a Company ${ }^{37}$

"Suspicion has fallen on a company."

Langston v. Amalgamated Union of Engineering Workers

"Joseph Langston is playing a lone hand."

Application des Gaz SA v. Falks Veritas Lid. ${ }^{39}$

"This is the first case in which in this court we have had to consider the Treaty of Rome. It comes about because of a tin can."

Agbor v. Metropolitan Police Commissioner ${ }^{40}$

"There is a civil war flaring in Nigeria. Sparks from it have come down in London. Some have landed on No. 35, Woodstock Road, London, N.W.11." Westem Excavating (E.C.C.) Ltd. v. Sharp ${ }^{41}$

"Mr Sharp was only employed by the China-Clay Co. for 20 months. He left of his own accord. Yet he has been awarded $£ 658$ as compensation for unfair dismissal. There seems something wrong about that award. What is it?"

32. Supra note 23 , at p. 42 .

33. [1976] Q.B.446, 453.

34. [1978] Q.B.69, 77 .

35. [1974] Q.B.624, 632.

36. [1955] 1 Q.B.253, 256 .

37. [1980] 1 All E.R.284, 285.

38. [1974] 1 All E.R.980, 983.

39. [1974] 3 All E.R.51, 53.

40. [1969] 2 All E.R.707, 708.

41. [1978] Q.B.761, 766. 
James Buchanan E Co. Ltd. v. Babco Fornarding and Shipping (U.K.) Ltd. ${ }^{42}$

"One thousand cases of whisky were stolen. It was on Friday evening, 24th January 1975."

R. v. Clerk to Lancashire Police Committee, ex parte Hook ${ }^{43}$

"In 1976 rumours were rife in Blackpool. Gossip abounded. About the goings on of the Chief Constable of Lancashire. He lived in the town. Not only about the chief constable himself. But other police officers too. And well-known citizens."

$R$. v. Criminal Injuries Compensation $B d$., ex parte Ince ${ }^{44}$

"It was soon after midnight on 14th/15th February 1971 in the Bloomsbury area of London. Men were seen acting suspiciously near the headquarters of the Territorial Army in Handel Street."

\section{The Historical Opener}

New Windsor Corp. v. Mellor ${ }^{45}$

"Today we look back far in time to a town or village green. The turf is old. Animals have grazed there for hundreds of years. Nowadays they are pleasant stretches of grass where people sit and talk. Sometimes they play cricket or kick a ball about. But in mediaeval times it was the place where the young men mustered with their bows and arrows. They shot at the butts. There might be stocks there where offenders were put for their petty misdemeanours. In the month of May they set up a maypole and danced around it. We have no record of when it all began, but the poet tells us:

'On the green they watched their sons

Playing till too dark to see,

As their fathers watched them once,

As my father once watched me ...."

Fennings Motors Ltd. v. Secretay of State for the Environment ${ }^{46}$

"The village has an attractive name, Dibden Purlieu. It goes back to the times of the Norman French."

\section{The Fatal and Deadly Opener}

Cooper v. Williams ${ }^{47}$

"Frederick Leslie Watkins was fatally injured in a road accident on December 4, 1959. He was driving a car. He himself was killed." 
Allen v. Fambo Holdings Ltd. ${ }^{48}$

"A man's head got caught in a propeller. He was decapitated and killed."

\section{The "This is the case" Opener}

\section{Cummings v. Granger ${ }^{49}$}

"This is the case of the barmaid who was badly bitten by a big dog."

Allgemeine Gold-und Silberscheideanstalt v. Customs and Excise Commissioners ${ }^{50}$

"This is the case of the three smugglers."

McIlkenny v. Chief Constable of West Midlands Police Force ${ }^{51}$

"This is the case of the Birmingham bombers."

\section{The Editorial Opener}

Allen v. McAlpine ES Sons Ltd. ${ }^{52}$

"In these three cases the law's delays have been intolerable. They have lasted so long as to turn justice sour."

Pike v. Pike ${ }^{53}$

"This is yet another case in which the doctrine of constructive desertion has been allowed to run wild."

Re Stone and Saville's Contract ${ }^{54}$

"Counsel for the vendor referred to this case as a comedy of errors. It is no comedy, but a history of errors."

Bremer Vulkan v. South India Shipping Corp. ${ }^{55}$

"When I was young, a sandwich-man wearing a top-hat used to parade outside these courts with his boards back and front, proclaiming 'Arbitrate, don't litigate'. It was very good advice so long as arbitrations were conducted speedily: as many still are in the City of London. But it is not so good when arbitrations drag on for ever."

Regazzoni v. K. C. Sethia (1944) Ltd. ${ }^{56}$

"The Union of South Africa is a country with a tremendous problem - some say an insoluble problem - in regard to the races in her midst."

Marsden v. Regan ${ }^{57}$

"This case ought to have been simple, but the lawyers have made it complicated."

48. [1980] I W.L.R.1252, 1254.

49. [1977] 1 All E.R.104, 106.

50. [1980] 2 All E.R.138, 139.

51. [1980] 2 All E.R.227, 231.

52. [1968] 1 All E.R.543, 546.

53. [1953] 1 All E.R.232, 235.

54. [1963] 1 All E.R.353, 354.

55. [1980] 1 All E.R.420, 425.

56. [1956] 2 Q.B.490, 511. See similarly Commission for Racial Equality v. Amari Plastics Lid. [1982] 2 W.L.R.972.

57. [1954] I All E.R475,482. 
R. ES T. Them Ltd. v. Reeves ${ }^{58}$

"Much of the litigation today is dominated by legal aid. The state subsidises one side by giving him unlimited financial assistance. It pays his lawyers' fees almost in full. It leaves the other side - who is often of very moderate means entirely unassisted. He has to bear his own costs with no recourse against the other side even when he wins. This is a grave injustice to the unassisted party. Parliament has done something to remedy it but the remedy is far from adequate. This case will show up the defects in the statute and in the regulations. It looks very much as if a hard-working husband and wife will be ruined by the fact that the other side was granted legal aid."

$R$. v. Chief Constable of Devon and Comwall ${ }^{59}$

"The coast of Cornwall is beautiful. Much of the inland is ugly. It is despoiled by china clay workings. Not far from them there is open farmland with small villages dotted around. Pleasant enough but not outstanding."

\section{The Non Sequitur Opener}

Rank Film Distributors Ltd. v. Video Information Centre ${ }^{60}$

"It is, it is a glorious thing, to be a Pirate King", said W. S. Gilbert (The Pirates of Penzance, I). But he was speaking of ship pirates. Today we speak of film pirates. It is not a glorious thing to be, but it is a good thing to be in for making money."

Cinnamond v. British Airports Authority ${ }^{61}$

"Many years ago Sir Edward Coke had a case about six carpenters. Now we have a case about six car-hire drivers."

The "This is an interesting case" Opener

Southam v. Smout ${ }^{62}$

"This is an interesting case."

Hussey v. Palmer ${ }^{63}$

"This case is of very considerable interest."

Woodhouse v. Nigerian Produce Marketing Co. Ltd. ${ }^{64}$

"This is an important case."

R. v. Local Commissioner for Adminstration for the N. and E. Area of England ${ }^{65}$

"This case is of legal significance, but more of human interest."

58. [1982] Q.B.172, 182.

59. [1982] Q.B.458, 465.

60. [1980] 2 All E.R.273, 277.

61. [1980] 2 All E.R.368, 380 .

62. [1963] 3 All E.R.104, 105. See similarly Bemays v. Prosser [1963] 2 All E.R.321; Pedley v. Cambridge Newspapers Letd. [1964] 2 All E.R.794, 796; and Dunford v. Dunford [1980] 1 All E.R.122, 123.

63. [1972] 3 All E.R.744, 745. See similarly Blair v. Tomkins and Osbome [1971] 1 All E.R.468, 469. 64. [1971] 1 All E.R. 665, 667. See similarly Wilishire v. Barrett [1965] 2 All E.R.271, 272 and R. v. Set. of State for the Home Department [1973] 3 All E.R.796, 798.

65. [1979] 2 All E.R.881, 893. 
$R$. v. Secretary of State for the Environment ${ }^{66}$

"We are here presented with a nice question."

Bankers Trust Ltd. v. Shapira ${ }^{67}$

"This is a new case."

$W$. v. $L^{68}$

"This is a sad case."

$\operatorname{Re} P A$. (an infant) ${ }^{69}$

"This is a poignant case."

Gainsborough Mixed Concrete Ltd. v. Duplex Petrol Installations Ltd. ${ }^{70}$

"This is a short but fortunately a very rare point."

Meacock E Co. v. Abrahams ${ }^{71}$

"This is a troublesome and difficult case."

\section{The Whimsical Opener}

Post Office v. Crouch ${ }^{72}$

"This case reminds me of the story of David and Goliath, with a difference. Goliath is winning all along the line. David has sought to find some stones in the brook called the Industrial Relations Act 1971; but every one of them has so far bounced off the invincible Goliath."

Tote Investors Ltd. v. Smoker ${ }^{73}$

"The defendant has in the past occasionally had a wager on a horse-race. Today she has been taking part in another game of chance or skill - the game of litigation."

Re Fames $^{74}$

"David Emlyn James is a lawyer who has gone astray. He was a partner in a firm of five lawyers practising at Lusaka in Zambia ... James went off with a sum of $£ 160,000$ belonging to the firm or its clients. He disappeared. But the story goes that, with the money in his pocket, he gambolled round Europe and came to rest for a while in England."

Braham v. F. Lyons E Co. ${ }^{75}$

"This case concerns an accident which took place ... in the sausage department of the defendant's ... food factory at Cadby Hall. At 2.30 in the afternoon the tea-break was called. The plaintiff, a married woman, was the first off towards the tea-bar. She was always, the judge said, pretty quick off the mark for her cup of tea."

66. [1976] 3 All E.R.90,92. See similarly Peck v. Anicar Properties Ltd. [1971] 1 All E.R.517, 518.

67. [1980] 3 All E.R.353, 355. See similarly Breen v. A.E.U. [1971] 1 All E.R.1148, 1151.

68. [1973] 3 All E.R.884, 886.

69. [1971] 3 All E.R.522.

70. [1968] 3 All E.R.267.

71. [1956] 3 All E.R.660, 661.

72. [1973] 1 W.L.R.766, 770. See similarly U.K.A.P.E. v. A.C.A.S. [1979] 2 All E.R.478, 480.

73. [1968] 1 Q.B.509, 514.

74. [1977] 1 All E.R.364, 367.

75. [1962] 1 W.L.R.1048, 1050. 
Ministry of Defence v. Feremiah ${ }^{76}$

"A woman's hair is her crowning glory, so it is said. She does not like it disturbed: especially when she has just had a 'hair-do'."

Howard v. Department of National Savings ${ }^{77}$

"This case will be of interest to those in the Civil Service - and elsewhere who are approaching retirement age. Unlike me!"

Capital Finance Co. v. Bray ${ }^{78}$

"This case has been a battle of wits between the hirer and a finance company.

The fortunes of war have fluctuated to and fro..."

Riddick v. Thames Board Mills Ltd. ${ }^{79}$

"It is eight years ago now since Robert Riddick, the plaintiff, was dismissed from his employment. Yet the manner of it has reverberated through the Law Courts ever since. He was a shift engineer in a mill at Worthington in Cumberland... Tree trunks went in at one end of the mill. Cardboard came out at the other end."

Shell International Petroleum Ltd. v. Gibbs ${ }^{80}$

"A gigantic ship was used for a gigantic fraud."

Routhan v. Arun District Council

"Once again we have to consider the doctrine of unity. It says that in law "husband and wife are one and the husband is that one." I remember well that it was invoked when I used to prosecute in the magistrates' courts. A wife was travelling on the railway using her husband's ticket. When she put forward the excuse: 'We are one in the eyes of the law,' the collector replied: 'But not in the eyes of the Southern Railway."'

George Mitchell Ltd. v. Finney Lock Seeds Ltd. ${ }^{82}$

"Many of you know Lewis Carroll's 'Through the Looking Glass.' In it there are these words (Ch. IV): "The time has come," the Walrus said, "to talk of many things: Of shoes - and ships - and sealing wax - Of cabbages - and kings -"' Today it is not 'of cabbages and kings' but of cabbages and what-nots. Some farmers ... ordered $30 \mathrm{lbs}$. of cabbage seed. It was supplied. It looked just like cabbage seed. No one could say it was not. The farmers planted it over 63 acres. Six months later there appeared out of the ground a lot of loose green leaves. They looked like cabbage leaves but they never turned in. They had no hearts. They were not 'cabbages' in our common parlance because they had no hearts."

76. [1980] Q.B.87, 96.

77. [1981] 1 W.L.R.542, 543.

78. [1964] 1 W.L.R.323, 326. Lord Denning proceeds to tell the facts of this case using the analogy of a battle with attack and counter-attack and reference to positions and entering the lists. This is a framework which he used in at least two other cases, Wallersteiner v. Moir, supra, note 8 and $E x p$. Rossminster Ltd. [1979] 3 All E.R.385, 396.

79. [1977] Q.B.881, 887.

80. [1982] 2 W.L.R.745, 771.

81. [1982] 2 W.L.R.144, 146.

82. [1982] 3 W.L.R.1036, 1040. This is the last judgment Lord Denning delivered. 


\section{The Picturesque Opener}

\section{Myers v. Milton Keynes Development Corporation ${ }^{83}$}

"In 1962 life was peaceful in Buckinghamshire. We mean in the northern part of it. It retained its old attractive qualities. Bletchley was the little market town serving the villages and farms round about. Two miles north of Bletchley there was the little hamlet of Walton. It had a manor house built in Tudor times, and a few cottages."

Miller v. Fackson ${ }^{84}$

"In summertime village cricket is the delight of everyone. Nearly every village has its own cricket field where the young men play and the old men watch. In the village of Lintz in County Durham they have their own ground, where they have played these last 70 years. They tend it well. The wicket area is well rolled and mown. The outfield is kept short. It has a good club house for the players and seats for the onlookers. The village team play there on Saturdays and Sundays. They belong to a league, competing with the neighbouring villages. On other evenings after work they practise while the light lasts. Yet now after these 70 years a judge of the High Court has ordered that they must not play there any more. He has issued an injunction to stop them. He has done it at the instance of a newcomer who is no lover of cricket. This newcomer has built, or has had built for him, a house on the edge of the cricket ground which four years ago was a field where cattle grazed. The animals did not mind the cricket. But now this adjoining field has been turned into a housing estate. The newcomer bought one of the houses on the edge of the cricket ground. No doubt the open space was a selling point. Now he complains that when a batsman hits a six the ball has been known to land in his garden or on or near his house. His wife has got so upset about it that they always go out at week-ends. They do not go into the garden when cricket is being played. They say that this is intolerable. So they asked the judge to stop the cricket being played. And the judge much against his will, has felt that he must order the cricket to be stopped: with the consequence, I suppose, that the Lintz Cricket Club will disappear. The cricket ground will be turned to some other use. I expect for more houses or a factory. The young men will turn to other things instead of cricket. The whole village will be much the poorer. And all this because of a newcomer who has just bought a house there next to the cricket ground." $8 \overline{5}$

85. See similarly Slater v. Clay Cross Co. Lid. [1956] 2 Q.B.264, 268; Fairey v. Southampton County Council [1956] 2 Q.B.439, 455; Wyld v. Sitver [1963] 1 Q.B.169, 180; Hoveringham Gravels Lid. v. Secretay of State for the Emcironment [1975] 2 All E.R.931, 933; Corpus Christi College v. Gloucestershire County Council [1982] 3 W.L.R.849,851. 
So there you have it, the distinctive Denning style of writing and the unique Denning opener. He did not always employ these techniques; many of his reasons for judgments are indistinguishable from those of his colleagues. However, when he used them his judgments became instantly recognizable. Mind you other judges, either intentionally or without realizing it, have aped the Denning judgment. $^{86}$

Can you imagine an actor doing a one-man show, "An Evening With Lord Denning", based upon his judgments? Perhaps the idea is far-fetched. In any event, such a show might well be brought to a close with one of Lord Denning's old folks. I imagine that you can easily guess whom I have in mind. There have been a number of characters who have appeared in Lord Denning's judgments. There was old Herbert Bundy of Yew Tree Farm, ${ }^{87}$ old Mr Baker of Dunsmore in Buckinghamshire, ${ }^{88}$ old Mrs Millward whose will was contested, ${ }^{89}$ old Mrs Annie Levenson who had one of the best pitches in the Petticoat street market in London, ${ }^{90}$ and old Mr Jones ${ }^{91}$ the scrap merchant. But, his most memorable word sketch was of none other than old Peter Beswick:

"Old Peter Beswick was a coal merchant in Eccles, Lancashire. He had no business premises. All he had was a lorry, scales and weights. He used to take the lorry to the yard of the National Coal Board, where he bagged coal and took it round to his customers in the neighbourhood. His nephew, John Joseph Beswick, helped him in the business.

In March 1962, old Peter Beswick and his wife were both over 70. He had had his leg amputated and was not in good health. The nephew was anxious to get hold of the business before the old man died. So they went to a solicitor, Mr Ashcroft, who drew up an agreement for them." 92

86. See, e.g., Levin v. Active Builders [1973] 6 W.W.R.297; Regina v. Pinx [1980] 1 W.W.R.77.

87. Lloyds Bank Lid. v. Bundy, supra note 24.

88. Inwards v. Baker [1965] 2 Q.B.29.

89. Millward v. Shenton [1972] 1 W.L.R.711.

90. $R$. v. Tomer Hamlets, ex p. Kayne-Levenson [1975] 1 Q.B.431.

91. Jones v. Jones [1977] 2 All E.R.231.

92. Beswick v. Beswick, supra note"1, at p. 549. 